\title{
Tatuagem, Gênero e Lógica da Diferença*
}

CÉSAR SABINO *

MADELT. LUZ

\section{RESUMO}

Este artigo analisa a lógica das tatuagens dos fisiculturistas e freqüentadores assíduos das academias cariocas de musculação e fitness, destacando o aspecto identitário de tal lógica e sua relação com a questão da diferença e das hierarquias sociais associadas, no estudo, à concepção cosmológica presente no pensamento metafísico ocidental. Tal concepção é confrontada com o perspectivismo ameríndio, no qual a diferença e o devir se apresentam como cerne do cosmos.

Palavras-chave: Tatuagem; gênero; fisiculturismo; identidade; diferença.

Recebido em: 03/07/06.

Aprovado em: 26/07/06. 


\section{Introdução}

Em diversas culturas de distintas complexidades, a tatuagem mobiliza olhares, reflete sentimentos, classifica e ordena subjetivamente o fluxo intermitente de indivíduos que lhe servem de tela e que nela buscam distinções simbólicas. Formando uma espécie de linguagem, os desenhos da epiderme apresentam uma "gramática" que possibilita organizar nas academias de musculação o regime da visibilidade institucional. Portanto, a tatuagem, do ponto de vista sociológico, é uma linguagem que "está intimamente ligada à organização social: [apresentando] motivos e temas [que] servem para exprimir diferenças de posição, privilégios de nobreza e graus de prestígio" (LÉVI-STRAUSS, 1975, p. 292).

A "gramática" epidérmica parece manifestar-se por intermédio de uma contradição: a maioria dos(as) tatuados(as) das academias pesquisadas escolhe seus desenhos após uma decisão pessoal que expressa a vontade de distinção. Tatuando-se, buscam singularizar suas figuras, sempre lhes conferindo uma característica diferencial, um detalhe específico; alguns até mesmo "inventam" seus desenhos ou "carregam" no estilo do mesmo ao se dirigirem ao tatuador. Toda essa atitude é engendrada na busca de uma individualidade relacionada à concepção de livre arbítrio e da distinção daquele que faz suas escolhas, pelas quais se vê como plenamente responsável.

De fato, segundo Sanders (1989), a tatuagem é um meio de individuação que tem a tarefa de demarcar a diferença em relação ao outro, tatuado ou não. Também constitui uma demarcação de inconformismo que pode expressar a incorporação de uma estética pessoal. Por outro lado, a grafia epidérmica permite reivindicar o pertencimento a uma categoria social, servindo como uma espécie de "etiqueta coletiva" (DURKHEIM, 1972, p. 113), simbolizando a filiação privilegiada a um grupo social específico que busca demarcar sua identidade coletiva em um processo de emblematismo.

Embora os fisiculturistas que participam freqüentemente de competições não as exibam em profusão (pois se os desenhos forem grandes poderão atrapalhar a visão de seus músculos ou desviar deles a atenção), as tatuagens estão presentes em inúmeros corpos nas academias de bodybuilders e "marombeiros". ${ }^{1}$ Numa pequena amostra da sociedade da performance e da aparência que constitui tais instituições, a superfície da pele realça o que ela reveste, aquilo que constitui objeto e propósito de todo o trabalho nesses locais: o músculo. O desenho gravado na epiderme surge como espécie de acabamento 
artístico num contínuo processo de busca por um ideal estético que envolve a encenação pública e a encarnação de papéis inerentes à dinâmica social. Se corpos musculosos "pavoneiam" (FOUCAULT, 1990, p. 9) pelos cenários repletos de espelhos, halteres e máquinas de exercícios, as tatuagens conferem a esses corpos o paroxismo da visibilidade que lhes é inerente.

Associadas, no Ocidente, à marginalidade até a década de 60 do século $\mathrm{XX}$ - quando estigmatizados como presidiários, motoqueiros dos Hell's Angels e marinheiros sem nenhuma patente desenhavam, por vezes de forma canhestra, imagens, palavras ou frases em seus corpos -, as tatuagens se tornaram atualmente parte do cotidiano das classes superiores. Decoram o corpo de indivíduos de idades variadas e demonstram a existência de um processo de circularidade cultural, no qual o poder de um item estigmatizado se torna emblema de status e domínio, invertendo o jogo social pela disputa de hegemonia simbólica das classes (GINZBURG, 1986; BAKTHIN, 1987).

Como os costumes de um povo, grupo social ou classe se organizam em sistema que apresenta um estilo, ocorre, por vezes, uma transposição cultural, uma reinterpretação de significados que fazem parte da própria dinâmica coletiva. Tal movimento é possível porque, dentre outros aspectos, os sistemas não se organizam em número ilimitado, sugerindo, de acordo com um clássico, que "as sociedades humanas, assim como os indivíduos - em seus jogos, sonhos e delírios -, jamais criam de modo absoluto, mas se limitam a escolher certas combinações num repertório ideal” (LÉVI-STRAUSS, 2000, p. 167).

Nas academias de musculação é possível perceber a produção coletiva - e inconsciente - de uma gramática imagética composta por inúmeros itens retirados e reinterpretados de outras culturas e/ou classes sociais. Tatuagens inspiradas em figuras mitológicas pertencentes às culturas da Polinésia Francesa e celta (denominadas tribais), japonesa, chinesa, hindu, balinesas, medieval, além de ideogramas e personagens de quadrinhos e de desenhos animados, que vão de super-heróis a anti-heróis, sem contar toda uma classificação "totêmica" inspirada em animais e fenômenos naturais, como cães, tigres, panteras, beijaflores, raios e estrelas, decoram os corpos dos freqüentadores, nem sempre fisiculturistas. Há também toda uma formação simbólica organizada em torno de objetos pertencentes à atual cultura de mercado e cyberculture, como marcas famosas de roupas e tênis (Nike, Adidas, Mizuno) e símbolos da computação, tais como @, além de códigos de barra, em geral estampados em locais estratégicos do corpo, como nuca, pulso ou região lombar. 
Canevacci (1993) ressalta que nas grandes megalópoles a linguagem visual assume papel efetivo, por sua instantaneidade. Propõe que o antropólogo das sociedades complexas preste detida atenção à linguagem dos signos visuais, pois essa linguagem ressalta o hibridismo, ou sincretismo cultural, que vem imperando nos centros urbanos. Tal hibridismo consolida o corpo como mapa social, expressando narrativas individuais e coletivas simultaneamente. Essas narrativas - da mesma forma que a bricolagem - são construídas por diversos itens, ou termos, pertencentes a culturas diversas tanto no tempo quanto no espaço. Desta maneira, por exemplo, uma mulher com ascendência alemã pode estampar em seu cóccix uma tatuagem "tribal", marca ancestral de homens taitianos, ou um entrelaçado celta, recriando a partir da mitologia germânica a concepção de "forças do infinito". Tudo isto com o objetivo - consciente - de não apenas tornarse singular, mas de se identificar - muitas vezes inconscientemente - com determinado grupo que freqüenta locais (os chamados points) e que consome produtos específicos, escuta determinado tipo de música e assim por diante.

Essa construção identitária, ao mesmo tempo concêntrica e excêntrica, está diretamente relacionada à dimensão visual das interações sociais. Quanto a esse aspecto, há a necessidade de expor signos, sejam eles músculos ou desenhos, corte e cor de cabelo, roupas ou ideogramas inscritos na pele. Esse apelo visual das sociedades complexas se faz presente delimitando espaços, demarcando diferenças e fazendo com que - no caso específico - os componentes das academias entrem no cenário iluminado da vida urbana com sua mise-en-scène singular inerente aos fluxos culturais preponderantes na cultura globalizada (HANNERZ, 1997; LUZ, 2003; LE BRETON, 2004), superexpondo-se num jogo que pode ser exemplificado pela produção do corpo-imagem nos campeonatos de fisiculturismo, nos quais cada fibra muscular deve ser mostrada e demonstrada em uma espécie de dissecação em vida do competidor. ${ }^{2}$ Mostrar, expor as entranhas musculares, exibir, alardear, ser notado, não apenas ostentando os adereços que compõem a sociedade de consumo, mas sendo dela o próprio adereço: "o corpo humano se torna um corpo panoramático que reflete, retroage e projeta infinitas combinações de sinais ventríloquos" (CANEVACCI, 1993, p. 23).

\section{Pele de homem. Pele de mulher}

As tatuagens nas academias de musculação dividem-se em femininas, masculinas e unissex. Mulheres tendem a tatuar determinadas figuras, como rosas e flores em geral, estrelas, borboletas, lua, sol, personagens femininas de 
histórias em quadrinhos, beija-flores, gatos e fadas. Ideogramas, desenhos tribais, palavras e frases em letra gótica, símbolos da computação, códigos de barra, corações, duendes, deuses ou deusas mitológicos são símbolos inscritos tanto na pele de homens quanto de mulheres. Águias, cruzes, panteras, tigres, dragões, demônios, caveiras, armas, arame farpado, sereias, mulheres nuas, tubarões, esqueletos com foice e capuz e, principalmente, cães da raça pitbull, são tatuagens masculinas. Os locais do corpo também definem o gênero: mulheres costumam tatuar a nuca, a região lombar (principalmente as chamadas tribais), os seios, as nádegas e virilhas, às vezes omoplatas, pés e calcanhares. Já entre os homens os desenhos situam-se principalmente no bíceps (em geral na parte exterior, mas também há desenhos na parte interior), costas, deltóide, antebraço e mais raramente abdômen, panturrilhas e peito.

As divisões estabelecidas pelos desenhos configuram a manutenção, reprodução mesmo, da gramática das diferenças inerentes às relações de gênero. Quando pensa escolher seu desenho (seja ele qual for), o indivíduo é "escolhido" por todo um conjunto de representações e práticas, estruturas subjetivas e objetivas reproduzidas pelo estilo de vida que articula e imita (EDMONDS, 2002). Tal sistema (inconsciente) aparta, organiza, distingue e constitui as (dis)posições sociais, alocando o indivíduo em uma, e exprimindo $a$ sua condição de gênero e classe. ${ }^{3}$

A tatuagem - surgida, como dito acima, entre pessoas antes consideradas escória social - tornou-se o emblema, ao menos nos casos das academias cariocas de musculação e fitness, o ethos de uma fração da classe média que hipervaloriza a exposição estética. Ela se apresenta como adorno e acabamento distintivo daqueles que buscam, no cultivo do corpo, dos músculos e da ausência de adiposidade, o sinal de destaque e superioridade sensitiva característicos dessa camada social. Tais estruturas subjetivas e objetivas são inscritas nos corpos em um duplo processo de "interiorização da exterioridade e exteriorização da interioridade" (BOURDIEU, 1983, p. 47). O aspecto "volátil" dessa ética estética característica de parcelas da sociedade urbana atual é reiterado pelo fato de que, tendo em princípio sido inscrições feitas na pele para toda a vida (ou seja, supostamente inalteráveis), hoje os grupos de tatuados adotam, por vezes, a estratégia de realizar outro desenho por cima da figura que já não mais satisfaz seus objetivos, cobrindo uma tatuagem com outra.

Mas o que significam essas tatuagens? Qual é sua função no contexto cultural estudado? Qual é o sentido do ato de tatuar-se para os que se tatuam? 
Adiantando uma via interpretativa, podemos repetir, a respeito das tatuagens, que elas, de uma forma ou outra,

conferem ao indivíduo sua dignidade de ser humano; operam a passagem da natureza à cultura, do animal "estúpido" ao homem civilizado. Em seguida, diferentes quanto ao estilo e à composição [...] expressam, numa sociedade complexa, a hierarquia dos status. Possuem, assim, uma função sociológica (LÉVI-STRAUSS, 2000, p. 183).

O desenho pode significar, para aquele que o tem em seu corpo, uma iniciação, o pertencimento, a identificação e a aceitação em determinado grupo:

[...] "mandei" esse dragão porque todo o pessoal que conheço tem tatuagem na academia, e no tatame, os caras mais "feras" têm as mais "iradas", as mais "maneiras" [...] aí mandei esse dragão no braço... Agora quero fazer um pitbull aqui nas costas (Carlos. 23 anos. Estudante, fisiculturista amador e lutador de jiu-jitsu).

$\mathrm{Ou}:$

Ah, fiz a borboleta na nuca ano passado... A galera toda lá do curso tinha, aqui na academia as garotas todas têm tatoo e piercing, cê sabe, né? É moda, sei lá [...] aí eu mandei essa aí na nuca e depois botei o piercing no umbigo [...] minha mãe reclamou muito, não me deu o dinheiro p'ra fazer, aí eu comecei a vender uns colares e pulseiras que eu mesma fazia e juntei dinheiro e fiz (Tatiana. 18 anos. Estudante).

$\mathrm{O}$ "sofrimento de ser escrito pela lei do grupo [a dor] vem acompanhado de um prazer, o de ser reconhecido, de se tornar uma espécie de palavra identificável e legível numa língua social, de ser mudado em fragmento de um texto anônimo, de ser inscrito em uma simbólica sem dono e sem autor" (DE CERTEAU, 2002, p. 232). Essas mensagens, não raro, estão relacionadas a uma suposta rebeldia presente nos movimentos estético-musicais de massa:

eu tenho o Bob Marley nas costas, ainda não acabei de fazer, vai demorar um tempo porque tem que colorir toda e é grande, pega toda as costas como 'cê tá vendo, né? [...] mandei essa tatoo por que gosto de reggae, me identifico com a mensagem do Bob, desde moleque eu gosto [...] de vez em quando aperto um, claro, né?, P'ra acalmar [...] então a tatoo tem tudo a ver [...]. É um lance cabeça e pele, sei lá (Filipe. 24 anos. Estudante, fisiculturista e skatista amador). 
Representações e práticas podem ser sugeridas pelos símbolos que os integrantes desse grupo urbano inscrevem na pele. As tatuagens mais comuns entre os fisiculturistas e freqüentadores assíduos das academias são aquelas que expressam força, autoridade e poder, relacionando-se este diretamente à virilidade. Junto a esses símbolos aparecem os ligados ao uso das drogas: ratos com corpo de fisiculturista e duendes musculosos fumando maconha, além de cogumelos de todos os tamanhos, alusão a um dito chá de cogumelo alucinógeno, e o próprio desenho da planta cannabis sativa.

Essas alusões às drogas merecem uma hipótese: o rito de iniciação de um marombeiro - aquele que se torna um freqüentador assíduo das academias, futuro fisiculturista - está relacionado ao uso coletivo dos esteróides anabolizantes. A maioria desses freqüentadores utiliza tais substâncias para melhorar desempenho no treinamento, aumentando a força, diminuindo o percentual de gordura e ampliando a massa muscular. A convivência com esta realidade repleta de substâncias químicas é, portanto, fato inevitável para os atuais frequientadores assíduos de academias. Para construir sua identidade e ser aceito no grupo (salvo raras exceções), o agente necessita passar pelo uso de tais substâncias. O processo ainda é reiterado pela concepção da boa forma física, a aparência, como sinônimo de saúde.

A droga faz parte do processo ritual de iniciação, rito de instituição, estando presente, de forma duradoura, no cotidiano dessas pessoas. Durante nosso trabalho de campo foi possível perceber que muitos utilizam drogas, além das "bombas", em festas ou momentos de lazer fora das academias. Tatuar sobre os músculos os símbolos relacionados ao consumo de drogas reitera e afirma o pertencimento do tatuado às estruturas objetivas e subjetivas que perpassam e constituem as práticas de cultivo da forma. Quando a tatuagem alude à iniciação às drogas, ela articula um processo que permite ao tatuado se fazer e se perceber como parte de um grupo.

A tatuagem também pode representar uma extensão e complemento do significado dos músculos e de tudo aquilo que está envolvido no seu cultivo. Figuras de cães ferozes, caveiras e cruzes, morte, símbolos de super-heróis, tigres, panteras e dragões, enfim animais e objetos considerados perigosos servem como advertência: "Cuidado, sou perigoso!" (DIÓGENES, 1998). A imagem do cão da raça pitbull, por exemplo, considerado feroz e de temperamento explosivo, surge na fala dos marombeiros como símbolo de força e daquilo que consideram qualidades: agressividade, destemor, ferocidade e potência: “[...] 
esse pitbull aqui [aponta para a imagem tatuada na panturrilha] é o meu mascote... Ele me dá força" (Pedro. 25 anos. Estudante). Ou:

A tatoo dessa fera aqui, no braço [...] nesse braço aqui, é do meu pitbull [...] eu me identifico com essa raça de cachorro, tem um movimento aí que quer acabar com eles, já ouviu falar, né? Dizem que o bicho é violento e coisa e tal [...] mas não vão conseguir, a gente que luta, que malha que gosta de esporte radical, a gente se amarra nesse bicho [...]. Vamos continuar criando [...] ele é nosso símbolo [...] forte. A mordida dele tem mais de uma tonelada de pressão, é isso aí, quero que meu soco também fique com uma tonelada de pressão... (João. 28 anos. Comerciante).

No que concerne às mulheres das academias, as figuras remetem à delicadeza, sensualidade e submissão. Tais desenhos acentuam esteticamente aquilo que tradicionalmente é considerado feminilidade em nossa cultura - ou os encantos, particularmente para os olhos masculinos, dessa feminilidade (FREYRE, 1986). Essas figuras são inscritas, geralmente, em regiões específicas do corpo da mulher: quadris, ventre, seios, virilhas, nuca. Se, no registro masculino, os desenhos ressaltam a musculosidade e a masculinidade de regiões do corpo que representam a virilidade e a força - e, portanto, a honra de ser homem - no registro feminino tais desenhos destacam o inverso, ligando a força feminina diretamente à sedução e à sexualidade. A tatuagem torna-se um adorno para as qualidades físicas diretamente ligadas ao gênero e às hierarquias de poder e relações de força a ele inerentes (LE BRETON, 2004). Mesmo aquelas figuras unissex, que poderiam dar a impressão de mudança de condição disfarçada pela mudança de posição, são inscritas nas regiões específicas do corpo nas quais ficam demarcadas as peculiaridades do contrapoder feminino radicado na dependência da dominação masculina. O desenho aí surge como adorno das qualidades sensuais e sedutoras da mulher - mesmo quando suposto sinal de "liberação" - sugerindo que o uso do corpo e da estética feminina continua subordinado e radicado no ponto de vista masculino, já que tais qualidades sensuais o são justamente por reiterarem a condição subordinada daquela que as apresenta:

o corpo feminino, ao mesmo tempo oferecido e recusado [nos jogos de sedução] manifesta a disponibilidade simbólica que [...] convém à mulher, e que combina um poder de atração e de sedução [...] adequado a honrar os homens de quem ela depende ou aos quais está ligada, com um dever de recusa seletiva que acrescenta ao efeito de "consumo ostentatório" o preço da exclusividade (BOURDIEU, 1999, p. 40-1). 
Demarcar regiões corporais que são alvo da cobiça sexual masculina por significarem a condição tradicional de mulher - parece funcionar como uma potencialização da sedução:

[...] a gente faz tatuagem na nuca, na virilha, perto do bumbum... É claro, né, são lugares de mulher fazer tatoo [...] Por quê? Porque dá um tchan, um destaque naquela parte que você acha que você tem de legal, que atrai os caras, que te dá aquele charme [...] entende? Se a mulher tem uma cintura bonita, fininha, um quadril largo, ela manda logo uma tribal aqui [aponta para a região abaixo dos rins], se ela tem um peitão bacana manda uma no peito, e aí vai... Tá ligado? Muita mina diz que faz na nuca, na bunda que é p'ra não enjoar da tatoo, porque ali ela não fica vendo o desenho o tempo todo, tudo bem, pode até ser, mas é muito mais p'ra dar um destaque naquela parte do corpo que ela acha que tem legal (Juliana. 20 anos. Estudante).

Entretanto, nem todas demonstram essa reflexividade a respeito da função da tatuagem: "Fiz tatoo porque gosto, não tem porquê... Achei legal e mandei no tornozelo, depois esse ideograma na nuca que quer dizer vida e amor; é isso fiz porque fiz e pronto" (Mariana. 25 anos. Jornalista).

Deste modo, ao se servir do seu próprio corpo, a mulher tatuada, ao menos neste caso específico, naturaliza uma ética estruturada culturalmente que a constrói como ser-para-o-outro. A tatuagem parece então surgir como uma espécie de adorno que realça e sensualiza determinados dotes físicos, conferindo e reiterando à portadora o poder (ou o contrapoder) e o quantum da sua feminilidade, construída como complemento e contraposição à masculinidade que a define em oposição a determinada sensualidade masculina que reside na musculosidade diretamente ligada à figura do homem senhor de sua força e de forças alheias. A dureza muscular, a grandeza e, por vezes, a rusticidade tornamse sinônimos para as mulheres dessas instituições, de excelência:

gosto de homem com cara de homem, corpo de homem, jeito de homem, não precisa ser um monstro de músculos, mas tem que ser malhado, tem que ser grande, espaçoso, tem que ter pegada [risos], jeito de macho, presença [...] que impõe respeito, autoridade [...] (Fabiana. 28 anos. Advogada).

O quadro a seguir sugere alguns aspectos classificatórios representados pelas figuras tatuadas nos corpos dos fisiculturistas e freqüentadores assíduos das academias de musculação e fitness. A classificação está diretamente relacionada à divisão de gênero, com suas relações de poder inscritas no corpo. 


\begin{tabular}{|c|c|c|c|c|}
\hline \multicolumn{5}{|c|}{ Classificação Triádica } \\
\hline & Homens & Unissex & Mulheres & \\
\hline \multirow[t]{2}{*}{$\begin{array}{l}(+) \\
\text { Agressivo/ } \\
\text { Forte }\end{array}$} & $\begin{array}{l}\text { Pitbull } \\
\text { Tigre } \\
\text { Águia } \\
\text { Pantera } \\
\text { Tubarão } \\
\text { Caveira } \\
\text { Armas } \\
\text { Morte (caveira } \\
\text { com foice) } \\
\text { Sol } \\
\text { etc. }\end{array}$ & $\begin{array}{l}\text { Tribal } \\
\text { Duende } \\
\text { Grifes (Nike, } \\
\text { Adidas) } \\
\text { Coração } \\
\text { Deuses(as) } \\
\text { Ideogramas } \\
\text { Circunstanciais } \\
\text { (Frases) } \\
\text { etc. }\end{array}$ & $\begin{array}{l}\text { Borboleta } \\
\text { Beija-flor } \\
\text { Estrela } \\
\text { Lua } \\
\text { Rosa } \\
\text { Mantras } \\
\text { Fada } \\
\text { Anjinho } \\
\text { etc. }\end{array}$ & $\begin{array}{l}(-) \\
\text { Delicado/ } \\
\text { Fraco }\end{array}$ \\
\hline & Corpo masculino & Ambos & & Corpo feminino \\
\hline $\begin{array}{l}\text { Regiões que } \\
\text { demarcam a } \\
\text { sensualidade } \\
\text { masculina }\end{array}$ & $\begin{array}{l}\text { Bíceps } \\
\text { Antebraço } \\
\text { Costas } \\
\text { Deltóides } \\
\text { Peitoral } \\
\text { Panturrilha }\end{array}$ & $\begin{array}{l}\text { As regiões } \\
\text { corporais relativas } \\
\text { ao sexo são } \\
\text { mantidas }\end{array}$ & $\begin{array}{l}\text { Regiões } \\
\text { demarcam a } \\
\text { sensualidade } \\
\text { feminina } \\
\text { (delicadeza, } \\
\text { sensualidade, } \\
\text { submissão) }\end{array}$ & $\begin{array}{l}\text { Virilhas } \\
\text { Ventre } \\
\text { Seios } \\
\text { Região lombar } \\
\text { Tornozelo } \\
\text { Nuca } \\
\text { Omoplata }\end{array}$ \\
\hline
\end{tabular}

\section{Tatuagem e lógica da identidade}

A existência da classificação triádica sugerida acima (tatuagem de homem, tatuagem de mulher e unissex), representada pelas figuras desenhadas na pele tanto de homens quanto de mulheres, talvez se refira a uma maleabilidade classificatória relacionada à conquista feminina da igualdade entre os sexos. É possível interpretar que tal ambigüidade apenas reitera que a mulher mudou de posição, mas, na maioria das vezes, não mudou de condição social, pois a disciplina que tradicionalmente se impõe ao seu corpo, delimitando sua situação em contraposição à condição masculina, conforme é possível perceber nas academias de musculação, ilustra a significação moral inscrita não apenas na sua aparência, mas em seus atos: costas a serem mantidas retas, andar requebrado e malemolente, quadril empinado, ausência de barriga, pernas fechadas ao sentar, seios propositadamente enfatuados, olhares de soslaio, etc., como se a feminilidade se medisse pela arte de se fazer delicada ou pequena (BOURDIEU, 1999; SIMMEL, 1993). As técnicas corporais femininas presentes nas sociedades complexas têm por efeito paradoxal - através da demonstração de disciplina e contenção, da oferta e da negação da oferta, de suposta dissimulação - concretizar e reiterar a ordem da sedução e da beleza femininas, socialmente construídas, mostrando e demonstrando, mesmo que circunstancial e sorrateiramente, os atrativos do corpo relacionados diretamente a sua sexualidade. 
Tanto a Sociologia como a Antropologia urbana têm elaborado abordagens teóricas que universalizam a dominação masculina. Assim, grosso modo, procedem as abordagens, por exemplo, de Lévi-Strauss e Bourdieu. ${ }^{4}$ Porém, novos estudos direcionados às sociedades tribais não-estratificadas da Amazônia e Nova Guiné não compartilham a universalidade dessa dominação, reiterando que em tais sociedades, em geral, as relações entre os gêneros são permeáveis e equilibradas (OVERING, 1984; CASTRO, 2002; GONÇALVES, 2001; LAGROU, 1998). Esse aspecto pode ser percebido, por exemplo, nas práticas da couvade, quando após o parto o homem também fica de resguardo. Essa prática seria inerente às sociedades nas quais as tarefas sexuais são relativamente flexíveis e o poder e o status feminino são altos. A couvade talvez sirva para estabelecer as tarefas do pai na vida da criança e para equilibrar as funções masculinas e femininas na criação destas.

Outro comportamento ritual que demonstra a imitação masculina do poder reprodutivo feminino é o "saignade", ritual de sangramento que imita a menstruação. Embora o sangue menstrual seja universalmente temido, em muitas culturas acredita-se também que ele carregue grande poder, sendo fonte e causa da saúde superior das mulheres e também causa do seu rápido crescimento. Assim, entre os Menihaku da Amazônia existem inúmeras ocasiões nas quais os homens menstruam simbolicamente, sendo a mais significante o ritual de perfuração das orelhas. Entre os Sambia das terras altas da Nova Guiné, o sangue menstrual também é identificado com a vitalidade, longevidade e feminilidade das mulheres. Para garantir saúde similar e longevidade, os homens Sambia produzem um ritual doloroso e brutal de imitação da menstruação, no qual se provoca o sangramento do nariz nos jovens durante cerimônias de iniciação (COUNIHAN, 1996). Sacralidade similar em relação ao sangue menstrual e exaltação do poder feminino foram percebidas por Osório (2000) em relação ao grupo de praticantes da bruxaria moderna no Rio de Janeiro, denominado Wicca.

Se em muitas culturas existe equivalência entre os gêneros, este não é o caso entre fisiculturistas e marombeiros. A classificação triádica existente no sistema simbólico da tatuagem provoca apenas uma ilusão igualitária, radicada na suposta maleabilidade simbólica da tatuagem unissex. As classificações dos desenhos da epiderme remetem às classificações ternárias destacadas no pensamento selvagem estudado por Lévi-Strauss (1975a e 1975). O autor sugeriu o caráter contínuo (ou de continuidade dinâmica do mundo) presente no raciocínio selvagem: "as sociedades que denominamos primitivas não concebem que possa existir uma fossa entre os diversos níveis de classificação [...] representam 
[tais níveis] como as etapas ou os momentos de uma transição contínua" (1975a p. 202). De acordo com Lévi-Strauss, na classificação primitiva não há a concepção estática da realidade, mas esta é percebida como processo dinâmico, com ausência de formais escaninhos estanques, como poderia sugerir uma análise apressada do binarismo presente nas temáticas estruturalistas.

A binaridade lógica (ou as partições ontológicas) apresentaria uma solução original no pensamento selvagem: sendo relação entre contínuo e descontínuo, o universo estaria "representado em forma de um continuum composto de oposições sucessivas" (LÉVI-STRAUSS, 1975a, p. 205). Conforme assinala Viveiros de Castro, as oposições binárias estáticas não estariam presentes nessa ontológica, pois, nesta, a identidade não seria nada mais do que um caso ou manifestação da diferença.

Apontando para um erro comum na Antropologia urbana, o autor assinala que uma antropologia das sociedades complexas não deveria se preocupar apenas em encontrar nas culturas e sociedades nacionais de tradição cultural européia ou eurasiáticas, a mesma lógica ou sentido constatada entre os "primitivos", mas, ao contrário, buscar as diferenças entre tais sociedades. $\mathrm{O}$ autor ainda afirma que uma concepção nublada do estruturalismo levou inúmeros pesquisadores de sociedades complexas, de modelos europeus ou asiáticos, a fazerem projeções de termos de uma cultura para outra. Tal equívoco apenas demonstra que uma projeção efetiva deveria ser a do tipo geométrico, em que as relações fossem preservadas e não os termos, por exemplo:

o “"equivalente” do xamanismo ameríndio não é o neoxamanismo californiano, ou mesmo o candomblé baiano. O equivalente funcional do xamanismo indígena é a ciência. É o cientista, é o laboratório de física de altas energias, é o acelerador de partículas. O chocalho do xamã é o acelerador de partículas de lá (CASTRO, 2002, p. 489).

Esse erro de projeção tem impedido muitos pesquisadores de perceberem as singularidades estruturais entre tipos de pensamento muito distintos e, portanto, também impedido de perceberem a singularidade das práticas socioculturais que apresentam conseqüências opostas em culturas diferentes. Ao transporem os termos e não analisarem comparativamente as relações, os pesquisadores mantêm um universalismo incapaz de perceber as implicações críticas que tais relações colocam para a base cosmológica, a racionalidade, do pensamento ocidental e suas práticas. 
Talvez a busca pelo imutável, pela identidade - entendida como essência metafísica -, característica da cultura ocidental (SCHÖPKE, 2004; DELEUZE, 1981), possa ser expressa, dentre outros aspectos, pelas tatuagens circunstanciais - em forma de frases. Tais tatuagens buscam eternizar um instante da vida (circunstâncias), um momento, uma data, uma relação através da fixação na pele de um nome ou mesmo um texto com supostos poderes mágico-protetores (LE BRETON, 2004). Apresentam-se sempre em forma de frases que formam ou não textos, ao contrário dos outros modelos de inscrição epidérmica. Um fisiculturista e instrutor de musculação de uma academia no bairro do Grajaú exibe, além de outras tatuagens espalhadas pelo corpo, uma tatuagem com esse tipo com letras góticas, com a inscrição "CULTURISMO" no antebraço:

Mandei escrever "CULTURISMO" no antebraço para todas as pessoas verem que a musculação e o fisiculturismo são a minha vida, a razão do meu viver; tudo que tenho consegui por intermédio do que faço... Então mandei escrever isso aí, p'ra todo mundo ver [...] ainda quero mandar escrever [a categoria] liberdade nas costas... (Pedro, 30 anos. Instrutor de musculação).

Ainda uma freqüentadora assídua das salas de musculação da mesma academia:

Eu tatuei na minha pele o que tenho na minha mente: palavra Deus em inglês [...] tatuei porque acho que tenho que lembrar a todo instante dele, agradecer o que tenho, saúde p'ra correr atrás do que preciso, por isso tatuei no pulso [...] também p'ra todo mundo ver que me protejo, sei lá é meio mágico [...] também [...] poder superior que você carrega no seu corpo (Carol. 18 anos. Estudante).

Se, a respeito das tatuagens entre tribos "primitivas" e neotribos urbanas, uma projeção apressada fosse feita, provavelmente se concluiria que a classificação triádica acima citada, presente nas academias de musculação, remeteria a uma concepção dinâmica de universo, na qual a diferença se apresentaria como constitutiva da realidade em ambos os pensamentos: o ocidental e o ameríndio. Mas não é isso que ocorre. Se os termos forem deixados de lado e as relações transpostas, perceberemos que, apesar das aparentes semelhanças nas classificações entre fisiculturistas e ameríndios, as lógicas de um e de outro são simetricamente invertidas. $\mathrm{O}$ aspecto triádico ameríndio está relacionado ao continuum da realidade compreendida como processo ou devir.

O aspecto triádico manifesta-se, por sua vez, tanto em um grupo quanto em outro (tribos ameríndias e neotribos urbanas), pela ampla variedade de 
desenhos que, se algumas vezes possuem os mesmos conteúdos (tema), variam amplamente na forma (estilo). O exemplo dos índios do grupo Pano na Amazônia remete ao aspecto nômade do pensamento ameríndio, em contraposição à característica sedentária do pensamento ocidental. Para esse grupo, as tatuagens permitem a identificação imediata do grupo ao qual pertence o indivíduo: "particularmente elaboradas são as tatuagens dos diversos grupos da área Juruá-Purus, caracterizadas por motivos angulares [...] cuja composição varia de grupo para grupo, tornando possível a imediata identificação" (SIGNORINI, 1968, p. 179 apud ERIKSON, 1986, p. 192).

De forma similar, as tatuagens entre os freqüentadores assíduos das academias cariocas de musculação e fisiculturismo classificam indivíduos pertencentes a subgrupos específicos numa lógica de "assimilação do mais longínquo conjuntamente a uma diferenciação máxima vis-à-vis do próximo" (ERIKSON, 1986, p. 192). Os mesmos desenhos, com suas variantes, podem ser encontrados entre subgrupos diferentes, da mesma forma que no seio de um mesmo subgrupo podem coexistir motivos bastante diferentes. Uma águia pode ser representada de inúmeras maneiras, aludindo a significados distintos para seções distintas, ou ter o mesmo significado para um grupo específico, porém sendo representada por estilos diferentes; formas que tendem a demarcar a singularidade daquele que porta o desenho (OSÓRIO, 2006). Essa diversidade faz alusão à lógica da diferença presente entre os ameríndios, em que o mundo é visto e compreendido como movimento incessante, "um todo interconectado de seres [...] com intencionalidade e agência semelhantes à nossa, capazes de adotar um ponto de vista" (LAGROU, 1998, p. 164).

Philippe Descola sugere a existência de modelos diversos de "ecologia simbólica": a naturalista (ocidental), onde vigora uma relação metonímica e natural entre natureza e sociedade, sendo a realidade, em última análise, radicada na natureza: os seres humanos teriam sua "essência" biológica como animais, diferenciando-se destes apenas pela cultura. A abordagem "totêmica", na qual a relação é puramente diferencial e metafórica, sendo uma série comparada por analogia a outra série; e, por último, o modo "anímico" (vigente nas cosmologias amazônicas), em que a relação natureza/cultura é metonímica e social, ou seja, inversamente às cosmologias ocidentais, estas últimas compreendem o cosmos como sendo todo cultura e não natureza. Objetos e animais teriam sociedades e se veriam como coletividade social; o animismo seria, portanto, um sociocentrismo (DESCOLA, 1992, 1996; CASTRO, 2002). 
Mas se em alguns momentos o processo lógico parece ser o mesmo da metafísica, tal fato não resiste a uma análise mais aprofundada. Entre os praticantes de fisiculturismo e freqüentadores das academias de musculação, no caso, a estrutura lógica do pensamento remete a uma classificação que tende a buscar a identidade, entendida (de forma avessa à dos ameríndios) enquanto negação da diferença, essência imutável do cosmos. Se para o grupo ameríndio o movimento expresso pela variação infinita de formas das tatuagens com o mesmo tema significa a "identidade" da diferença, para outro, o mesmo movimento busca demarcar a identidade compreendida como manifestação do imutável, cópia imperfeita deste. A tatuagem, no caso dos marombeiros e fisiculturistas, expressaria a concepção inconsciente de que o cosmos não é um devir, um tornar-se imanente, e sim parte volátil de uma realidade metafísica superior essencialmente imutável, à moda platônica. Se no pensamento domesticado, ou dito ocidental (LÉVI-STRAUSS, 1975; LUZ, 2004; BOURDIEU, 2005), a identidade é ausência de diferença (e esta uma carência, uma falha) - o que leva à busca da essência estática do cosmos na filosofia metafísica -, no pensamento selvagem, ou dito nômade, o contrário ocorre: a identidade é um caso particular, circunstancial e delimitado da diferença (CASTRO, 2000; MARQUES, 2003; DELEUZE, 2006).

Tal processo lógico está diretamente relacionado ao perspectivismo ameríndio. ${ }^{5}$ A mesma variabilidade das figuras tatuadas, existente entre ameríndios e fisiculturistas e marombeiros, expressa, em última análise, sentidos opostos. No caso dos marombeiros, essa variabilidade é representada pelo fato de o mesmo desenho ser realizado no que eles mesmos denominam estilos. Esses estilos apresentam diversidade (tradicional, oriental, new school, tribal, etc.). Por exemplo, há o estilo tribal, que pode ser visto em variações como a celta, o estilo samoano ou taitiano; há o estilo mecânico, que representa figuras com formas cibernéticas; há o estilo oriental, com desenhos inspirados na arte chinesa e japonesa, mormente da Yakusa (no caso japonês), e assim por diante. Esse movimento - de variação da forma e do estilo - é compreendido pelo fisiculturista como busca pela demarcação identitária que delimita a singularidade da sua pessoa enquanto marca que deseja a imutabilidade e não como demonstração da diferença e do devir imanente ao cosmos, processo que ocorre no caso ameríndio, em que "a distância intensiva e extrínseca entre as partes converte-se em diferença intensiva, imanente a uma singularidade dividida" (CASTRO, 2002, p. 293). Enquanto a variabilidade e a continuidade para um significam o próprio movimento cosmológico (o devir), para outro constituem 
busca pela singularidade identitária, marca de uma "essência" imutável (a identidade). Se a singularidade é, e afirma o processo, em um aspecto, em outro o processo deve ser negado pela própria busca da singularidade. Nesta interpretação, enquanto o pensamento domesticado dos bodybuilders e marombeiros afirmaria o transcendente, o pensamento selvagem ameríndio, por sua vez, se apresentaria como a pura manifestação da imanência.

\section{Conclusão}

Se as tatuagens remetem a um tipo de sistema simbólico ou gramática social, tal gramática nas academias de musculação e fisiculturismo remete às relações hierárquicas de gênero e status, relações que produzem e são produzidas pelas práticas cotidianas dos atores. Essa mesma lógica apresenta uma singularidade triádica simetricamente invertida em relação ao pensamento ameríndio. Este concebe o mundo - visto sem a cisão natureza/sociedade, posto que tudo é sociedade e "humanidade" - como devir e diferença, enquanto a lógica dos marombeiros e fisiculturistas (pequena amostra da lógica metafísica) concebe a diferença, o devir como defeito, parte desequilibrada e tortuosa de uma realidade superior imutável, pura, esta sim, máxima identidade e simetria.

Se, para uma forma de pensamento, o respeito à diferença e à assimetria é a base de todo o processo de pensamento e de organização prática da vida, para outra, a diferença e a assimetria surgem como males a serem combatidos em nome de uma identidade suprema e imutável, manifestação pura da perfeição e positividade. Se a lógica ou racionalidade ameríndia, ao contrário, aceita a diferença e o movimento como positivos, absorvendo e respeitando seu acontecimento, a lógica ou racionalidade ocidental vê na diferença a ameaça à sua integridade, fato que remete, na prática, à dificuldade de tais pensamentos (presentes nas sociedades complexas capitalistas) lidarem com as manifestações do outro e da alteridade.

Enquanto uma lógica absorve positivamente essa alteridade compreendendo-a com cerne de todo devir cósmico, a outra combate a mesma alteridade - até mesmo quando fala em dialética - fazendo-a desaparecer no seio de uma identidade imutável que deve, por fim, dominar, ordenar, administrar e subjugar a diferença ao império do "igual" e do "mesmo".

O que se deve, em termos práticos, destacar neste processo é que, em um tipo específico de pensamento, o respeito à diferença e à assimetria produz 
relações sociais marcadamente igualitárias e simétricas (como se pode notar nas relações de gênero entre os ameríndios); enquanto o outro tipo (o pensamento racionalista ocidental), que se pretende defensor da igualdade e da simetria sociais, produz regras na prática assimétricas, instituindo relações sociais, inclusive as de gênero, marcadas por desigualdades.

\section{Referências}

BOURDIEU, Pierre. Questões de Sociologia. Rio de Janeiro: Marco Zero, 1983. . O poder simbólico. Lisboa: Difel, 1989. . A dominação masculina. Rio de Janeiro: Bertrand Brasil, 1999. . Esboço de auto-análise. São Paulo: Companhia das Letras, 2005.

CANCLINI, Nestor Garcia. Consumidores e cidadãos. Rio de Janeiro: Ed. UFRJ, 1995.

CANEVACCI, Máximo. A cidade polifônica. São Paulo: Studio Nobel, 1993. COUNIHAN, Carole. Food, Sex and Reproduction: penetration of gender boundaries. Horizontes Antropológicos, Porto Alegre. Ano 2, n. 4, p. 104117, 1996.

DE CERTEAU, Michel. A invenção do cotidiano: artes de fazer. Petrópolis: Vozes, 2002. v. 1.

DELEUZE, Gilles. Nietzsche e a Filosofia. Porto: Rés, 1981.

DESCOLA, Phillipe. Societies of natures and nature of society. In: KUPER, Adam (Org). Conceptualizing Society. London: Routledge, 1992.

. Constructing natures. Symbolic ecology and social practice. In: DESCOLA, P.; PALSON, G. (Orgs). Nature and Society: anthropological perspectives. London: Routledge, 1996.

DIÓGENES, Glória. Cartografias da cultura e da violência. Gangues galeras e o movimento hip hop. São Paulo: Annablume, 1998.

DURKHEIM, Emile. As regras do método sociológico. São Paulo: Companhia Editora Nacional, 1972. 
EDMONDS, Alexander. No universo da beleza: notas do campo sobre cirurgias plásticas no Rio de Janeiro. In: GOLDENBERG, M. (Org). Nu e vestido. Rio de Janeiro: Record, 2000.

ERIKSON, Phillipe. Alterité, tatouage et anthropologie chez le Pano: la Beliqueuse Quête du Soi. JSA, Paris, v. 82, p. 185-209, 1986.

FOUCAULT, Michel. História da sexualidade I. Rio de Janeiro: Graal, 1980. FREYRE, Gilberto. Modos de homem modas de mulher. Rio de Janeiro: Record, 1986.

GOLDENBERG, Mirian. De perto ninguém é normal. São Paulo: Record, 2004. GONÇALVES, Marco Antônio. O mundo inacabado: ação e criação em uma cosmologia pirahã. Rio de Janeiro: Ed. UFRJ, 2001.

HANNERZ, Ulf. Fluxos, fronteiras e híbridos: palavras-chave da antropologia transnacional. Mana, Rio de Janeiro, v. 3.n. 1, p. 8-38, 1997.

LAGROU, Elsje Maria. Caminhos, duplos e corpos: uma abordagem perspectivista da identidade e alteridade entre os Kaxinawá. 1998. Tese (Doutorado em Antropologia) - Universidade de São Paulo. São Paulo, 1998.

LE BRETON, David. Sinais de identidade: tatuagens, piercings e outras marcas corporais. Lisboa: Miosótis, 2004.

LÉVI-STRAUSS, Claude. El pensamiento salvaje. Mexico: FDE, 1975a.

As organizações dualistas existem? In: . Antropologia

estrutural. Rio de Janeiro: Tempo Brasileiro, 1975.

Tristes trópicos. São Paulo: Companhia das Letras, 2000.

LUZ, Madel T. Novos saberes e práticas em saúde coletiva. São Paulo: Hucitec, 2003.

. Natural, racional, social: razão médica e racionalidade científica moderna. São Paulo: Hucitec, 2004.

MARQUES, António. A Filosofia perspectivista de Nietszche. São Paulo: Unijuí, 2003.

MAUSS, Marcel. Uma categoria do espírito humano: a noção de pessoa, a noção de "eu". In: . Sociologia e Antropologia. São Paulo: EPU/ Edusp, 1974. v.1. 
OVERING, Joana. Dualism as an Expression of Difference and Danger Marriage Exchange and Reciprocity among of Piaroa of Venezuela. In: KESINGER, K. (Org). Marriage Practice and Lowlands South America. Chicago: University of Illinois Press, 1984.

OSÓRIO, Andréa. O corpo da bruxa. In: GOLDENBERG, M. (Org). Nu e vestido. Rio de Janeiro: Record, 2000.

. o gênero da tatuagem. Tese (Doutorado em Antropologia) Instituto de Filosofia e Ciências Sociais, Universidade Federal do Rio de Janeiro. Rio de Janeiro, 2006.

SABINO, César. Anabolizantes: drogas de Apolo. In: GOLDENBERG, M. (Org). Nu e Vestido. Rio de Janeiro, Record, 2002.

O peso da forma. Cotidiano e uso de drogas entre fisiculturistas. 2004. Tese (Doutorado em Antropologia Cultural) - Programa de Pós-Graduação em Sociologia e Antropologia, Instituto de Filosofia e Ciências Sociais, Universidade Federal do Rio de Janeiro (PPGSA/IFCS/UFRJ), Rio de Janeiro, 2004.

SANDERS, Clifton. Customizing the Body: the ar\$t and cult\$ure of tat\$ooing. Philadelphia: Temple University Press, 1989.

SCHÖPKE, Regina. Por uma filosofia da diferença. Gilles Deleuze: o pensador nômade. São Paulo: Contraponto, 2004.

SIMMEL, Georg. Como as formas sociais se mantêm. Rio de Janeiro: Ática, 1983. (Col. Os Grandes Cientistas Sociais).

VIVEIROS DE CASTRO, Eduardo. Atualização e contra efetuação do virtual na sociedade amazônica. O processo do parentesco. ILHA. Revista de Antropologia. Florianópolis: UFSC, v. 2. n. 1, dez., p. 5-47. 2000.

Naif, 2002.

. A inconstância da alma selvagem. Rio de Janeiro: Cossac \& 


\section{NOTAS}

* Este artigo é fruto parcial do trabalho de campo (observação participante e etnográfica, com realização de entrevistas gravadas e escritas, formais e informais), realizado em 12 academias de musculação e ginástica das zonas Norte e Sul da cidade do Rio de Janeiro, durante os anos de 1998 a 2004, visando à elaboração de tese de doutorado em Antropologia Cultural (SABINO, 2004). Relata também algumas análises do grupo Racionalidades Médicas, do Instituto de Medicina Social da UERJ. Foram entrevistados 310 freqüentadores assíduos dessas instituições (200 homens e 110 mulheres, com idade entre 16 e 55 anos), sendo que, destes, 101 possuíam tatuagens (63 mulheres e 38 homens).

- Pesquisador associado (FAPERJ) no grupo de pesquisa CNPq Racionalidades Médicas e Práticas Corporais, do Instituto de Medicina Social da UERJ. Endereço eletrônico: cesarsabino@hotmail.com.

- Professora titular no Departamento de Políticas e Instituições de Saúde do Instituto de Medicina Social da UERJ; coordenadora do grupo de pesquisa CNPq Racionalidades Médicas e Práticas Corporais. Endereço eletrônico: madelluz@ superig.com.br.

${ }^{1}$ Em linguagem "nativa" marombeiro significa todo(a) aquele(a) que freqüenta com assiduidade academias de musculação e ginástica, apresentando corpo moldado ("sarado", como é dito) pelos exercícios. A palavra deriva de maromba, vara usada pelo funâmbulo para se equilibrar na maroma, corda na qual caminha. Também pode significar o peso com o qual o funâmbulo mantém seu equilíbrio (SABINO, 2002).

${ }^{2}$ Talvez o fisiculturismo seja uma manifestação de um possível movimento de estetização das entranhas. Essa estetização tem seu maior expoente artístico no médico alemão Gunther Von Haggens, criador da escola chamada body work. O médico-artista inventou um processo de plastificar cadáveres, denominado plastination. Essa técnica conserva os corpos mortos, transformando-os numa espécie de bonecos hiper-realistas expostos em galerias de arte. Em 2002 Von Haggens realizou uma exposição de vários cadáveres na Atlantis Gallery. Havia entre eles uma mulher grávida de oito meses, com útero aberto mostrando o feto. O trabalho do médico tem alcançado notoriedade, pois o mesmo tem apresentado programas nas televisões européias nos quais ele disseca cadáveres ao vivo (cf. O Globo. Sábado, 12/Abril/2003. Caderno Prosa e Verso, p. 2).

${ }^{3}$ Sobre a tatuagem - assim como sobre o músculo hiper-inflado do fisiculturista, parafraseando Lévi-Strauss (1975), podemos dizer que é feita para o corpo, mas num outro sentido, o corpo, neste caso específico, é predestinado à decoração por figuras e músculos, posto que é somente 
por, e através da decoração, que ele recebe sua dignidade social e significação. A decoração é concebida para o corpo, mas o próprio corpo não existe senão por ela. A dualidade é, em definitivo, a do ator e de seu papel, e é a noção de máscara que nos traz sua chave. Essa alusão à máscara é significativa, posto que persona em latim tem o mesmo sentido: "é clássica a noção de persona latina: máscara, máscara trágica, máscara ritual, máscara de antepassados” (MAUSS, 1974, p. 225). A etimologia evoca o quanto o agente é composto em suas ações por forças sociais inscritas em seu corpo, conferindo-lhe identidade. A persona, enquanto produção social, vive e repete - embora na diferença - as forças criadoras coletivas. Enquanto máscara, a persona coloca em cena ou participa da encenação dos tipos sociais. Le Breton (2004) ressalta que atualmente as tatuagens não são apenas uma forma de singularizar, mas de tocar as jovens gerações em seu conjunto, confundindo todas as condições sociais e os gêneros - elas não são exclusivamente apenas de homens.

${ }^{4}$ Bourdieu (1999, p. 43), por exemplo, escreve: "simbolicamente votadas à resignação e à discrição, as mulheres só podem exercer algum poder voltando contra o forte sua própria força, ou aceitando se apagar, ou pelo menos negar um poder que elas só podem exercer por procuração (como eminências pardas)".

${ }^{5} \mathrm{O}$ perspectivismo ameríndio é descrito da seguinte forma por Eduardo Viveiros de Castro (2002, p. 350-1): “o estímulo inicial para esta reflexão foram as numerosas referencias, na etnografia amazônica, a uma concepção indígena segundo a qual o modo como os seres humanos vêem os animais e outras subjetividades que povoam o universo - deuses, espíritos, mortos, habitantes de outros níveis cósmicos, plantas, fenômenos meteorológicos, acidentes geográficos, objetos e artefatos - é profundamente diferente do modo como esses seres vêem os humanos e a si mesmos. Tipicamente, os humanos em condições normais vêem os humanos como humanos e os animais como animais; quanto aos espíritos, ver esses seres usualmente invisíveis é um signo seguro de que as 'condições' não são normais. Os animais predadores e os espíritos, entretanto, vêem os humanos como animais de presa, ao passo que os animais de presa vêem os humanos como espíritos ou como animais predadores: 'o ser humano vê a si mesmo como tal. A lua, a serpente, o jaguar e a mãe da varíola o vêem, contudo, como um tapir ou um pecari que eles matam', anota Baer sobre os Machiguenga. Vendo-nos como não-humanos, é a si mesmo que os animais e espíritos se vêem com humanos. Eles se apreendem como ou se tornam antropomorfos quando estão em suas próprias casas ou aldeias, e experimentam seus próprios hábitos e características sob a espécie da cultura: vêem seu alimento como alimento humano (os jaguares vêem o sangue como cauim, os mortos vêem os grilos como peixes, os urubus vêem os vermes de carne podre como peixe assado, etc.), seus atributos corporais (pelagem, plumas, garras, bicos, etc.) como adornos ou instrumentos culturais, seu sistema social como organizado 
identicamente às instituições humanas (com chefes, xamãs, ritos, regras de casamento, etc.). Esse ver 'como' refere-se literalmente a perceptos, e não analogicamente a conceitos, ainda que, em alguns casos, a ênfase seja mais no aspecto categorial que sensorial do fenômeno; de qualquer modo, os xamãs, mestres do esquematismo cósmico dedicados a comunicar e administrar as perspectivas cruzadas, estão sempre aí para tornar sensíveis os conceitos ou inteligíveis as intuições. Em suma, os animais são gente, ou se vêem como pessoas. Tal concepção está quase sempre associada à idéia de que a forma manifesta de cada espécie é um envoltório (uma roupa) a esconder uma forma interna humana, normalmente visível apenas aos olhos da própria espécie ou de certos seres transespecíficos, como os xamãs. Quando estão reunidos em suas aldeias na mata, por exemplo, os animais despem as roupas e assumem a figura sua figura humana. Em outros casos a roupa seria como que transparente aos olhos da própria espécie e dos xamãs humanos."

\section{ABSTRACT}

\section{Tatoo, Gender and the Logic of Difference}

This article analyzes the tatoos logic of the bodybuilders and gyms frequenters in Rio de Janeiro city, detaching the identity aspect of such logic and its relation with the question of difference and the social hierarchies associated, in the study, to the cosmological conception present in Western metaphysical thought. Such conception is collated with the Amerindian perspectivism, in which the difference and the becoming are presented as the cosmos essence.

Key words: Tattoo; gender; bodybuiding; identity; difference. 